\title{
Probit Regression Analysis in Estimating the Effect of Learning Assisted by Cabri 3D on Students' Mathematical Understanding Ability
}

\author{
Leni Marlena ${ }^{1}$, Esti Ambar Nugraheni ${ }^{1}$ \\ ${ }^{1}$ Pendidikan Matematika, FKIP, UHAMKA \\ Corresponding author: lenimarlena@uhamka.ac.id
}

\begin{abstract}
Social connection requires each individual to have a strong understanding of the environment. Concept understanding can be improved through software. The goal of this research is to predict the effect of mathematics learning using Cabri 3D software. The dependent variable is the mathematics concept of understanding ability. The independent variable is the dummy variable that determines the type of the class. The value of the dummy variable for the class that applied the Problem-based Learning (PBL) assisted by Cabri 3D is 1 and the value of the dummy variable for class without Cabri 3D is 0. Students' mathematics ability was measured by a percentage or probability. The values of the mathematical concept understanding obtained by students were converted into probability values. After the data has been collected, probit regression analysis was used to see the probability of success of mathematical concepts understanding of those who were taught using PBL and those who were taught without using PBL without Cabri 3D. The results of data analysis showed that the types of classes significantly affect the mathematical concept of understanding ability. Thus, it can be concluded that learning with Cabri 3D can improve the mathematical concept of understanding ability.
\end{abstract}

Keywords: Cabri 3D; PBL; Probit Regression; Mathematical Concept Understanding.

\section{INTRODUCTION}

The world of education must now adjust to the presence of the industrial revolution era 4.0 (Helaluddin \& Wijaya, 2019; Kusmawati \& Surachman, 2019). The world of mathematical education must also be ready to face this era with a learning process that utilizes Information and Communication Technology (ICT) to facilitate teaching and learning in the classroom (Imanullah, Dahlan, \& Sobari, 2019). In the world of mathematics education, one of the problems that often arises is in mathematical understanding (Tanjung \& Nababan, 2019; Wendayani, Ratnaningsih, \& Muhtadi, 2019). Mathematical understanding is a very important aspect in learning mathematics (Sopia, Hartoyo, \& Sugiatno, 2019). mathematical understanding allows one to be able to solve problems better (Lestari \& Lies, 2019; Rasmin, Sudia, \& Kadir, 2019). Based on previous research, the students' mathematical understanding was still low (Unaenah \& Sumantri, 2019).

Nowadays, there have been many computer programs being developed to help teachers and students in the process of learning and teaching mathematics. One of them is Cabri 3D, Geogebra, Carmetal, Bagatrix, Wingeom, Geometer's Sketchpad, Algebrator, Lindo, Graphmatic, and Cabri Geometry II (Lebamovski \& Gospodinov, 2019). In this research, the software used was Cabri 3D because the focused on the material was the planes.

3D Cabri soft software can visualize the forms of planes (Aryanti \& Ferdianto, 2019). The use of instructional media is expected to be able to provide conceptual understanding to students, so students are more active in the process of learning mathematics. Cabri 3D is a dynamic-geometry software that can be used to help students and teachers overcome some 
difficulties and make the learning of three-dimensional geometry easier and more interesting (Accascina \& Rogora, 2006; Yanty Putri Nasution, 2017)

One learning approach that allows students to be actively involved in obtaining concepts by solving problems is the Problem-based Learning model (Kristyanawati, Suwandi, \& Rohmadi, 2019). Through the problems presented by the teacher, students can develop their creativity and construct their new knowledge which includes the ability to formulate problems, analyze problems, determine problem-solving, and make conclusions. A conducted classroom action research shows that the Problem-based Learning model can improve students' mathematical concept understanding (Waluyo \& Siswanto, 2019). The results of his observations showed that the average score on the pre-cycle test was 66.81 (moderate), the average score on the first cycle test was 76.97 (high), and the average value on the second cycle was 86.83 (high) (Zulfa, A., Warniasih, K., \& Wardono, 2019).

Research on Cabri 3D-assisted learning on the ability to comprehend mathematical concepts has been done by previous researchers, namely research on the 3D Cabri-based student worksheet can improve mathematical concept understanding so that the learning process becomes effective and efficient (Hendriana, 2019), the application of Cabri 3D learning media on the mathematical concept understanding can help students in learning because they are invited to learn in real terms (Sumliyah, 2019). And in other studies (Hartatiana, Darhim, \& Nurlaelah, 2017a, 2017b; Hendriana, Nuriadin, \& Rachmaeni, 2019; Muhammad, Purwanto, \& Muji Prisnaini, 2017; Witanto, 2019).

Based on previous research, the novelty in this study is the use of regression analysis in determining the influence of the Cabri 3D software on students' mathematical concept understanding. The statistical analysis used was Probit regression. The use of Probit regression can provide more information than just using the two population mean values. By using Probit regression analysis, the results of this study will be able to provide the information on the significance effect of Cabri 3D software on mathematical concept understanding and its ability to estimate the percentage of mathematical concept understanding of students who were taught using the Problem-based Learning assisted by Cabri 3D software and those who were not taught using Cabri 3D software.

\section{THE RESEARCH METHODS}

The data was collected from the eighth-grade students of SMPN 21 South Tangerang. The sample taken was the class VIII-1 as the class taught by using Problem-based Learning assisted by Cabri 3D V2 and class VIII-4 as the class taught by using Problem-based Learning without Cabri 3D V2. The sample size for the class given the Problem-based Learning with Cabri 3D V2 was 33 students while the sample size for the class given the model Problembased Learning without Cabri 3D V2 was 34 students. The material used in this study was the material of the plane.

The independent variable of this study was a dummy variable, i.e. the class given the Problem-based Learning assisted by Cabri 3D V2 notated by the number "1". The class given PBL without 3D Cabri V2 was notated by the number "0". Then, the dependent variable was the value of students' mathematical concept understanding ability in the form of a percentage. 


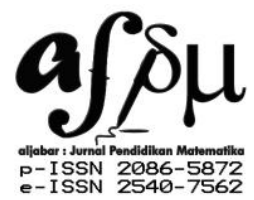

Al-Jabar: Jurnal Pendidikan Matematika

Vol. 10, No. 2, 2019, Hal 319 - 326

The instrument used to measure students' mathematical concept understanding was a 7-items test on students' mathematical concept understanding of the material of the plane in the form of descriptions that have passed the validity and reliability tests.

In general, the Probit model can be stated in the following equation:

$$
\text { probit }[\pi(\mathrm{x})]=\beta_{0}+\beta_{1} \mathrm{x}_{1}+\beta_{2} \mathrm{x}_{2}+\ldots+\beta_{\mathrm{p}} \mathrm{x}_{\mathrm{p}}
$$

The Probit regression parameters are $\beta_{0}, \beta_{1}, \ldots, \beta_{\mathrm{p}}$ and free variables are $\mathrm{x}_{1}, \mathrm{x}_{2}, \ldots, \mathrm{x}_{\mathrm{p}}$ (Agresti, 2006). The Maximum Likelihood Estimation method was employed to estimate the Probit regression parameters. The independent variables contained in this Probit model were then statistically tested to determine their significance for the response variables. The statistical tests conducted were a partial test, overall test, and model suitability test. Data processing to get the estimated value of Probit regression parameters and statistical testing was done with the help of SPSS software.

The partial test was carried out to test the significance of the coefficient $\beta$ partially by comparing the alleged $\beta$ with its default error estimator. The parameter was $\beta_{1}$ tested using the Wald test (W test) (Hosmer, Lemeshow, \& Sturdivant, 2013). The statistical hypotheses used were as follows:

$\mathrm{H}_{0}: \beta_{1}=0$ (class does not significantly influence students' mathematical concept understanding ability)

$\mathrm{H}_{1}: \beta_{1} \neq 0$ (class has a significant effect on students' mathematical concept understanding ability), the equation used was:

Description:

$$
W_{i}=\frac{\widehat{\beta}_{i}}{\widehat{S E}\left(\widehat{\beta}_{i}\right)}
$$

$\widehat{\beta}_{1} \quad=$ estimator for $\beta_{1}$

$\widehat{\mathrm{SE}}\left(\widehat{\beta}_{2}\right)=$ standard error estimator of $\beta_{1}$

In this case, the $\mathrm{W}$ test statistic follows the standard normal distribution, so testing was done by comparing the Wald test statistics with the standard normal distribution at the real level $\alpha$. If the value of $|\mathrm{W}|>\mathrm{Z}_{\alpha / 2}$ or $\mathrm{p}$-value $<\alpha$ then $\mathrm{H}_{0}$ is rejected.

The whole test was carried out to check the significance of the coefficients $\beta$ simultaneously. In general, the hypothesis for the whole test is as follows:

$$
\begin{gathered}
\mathrm{H}_{0}: \beta_{1}=\beta_{2}=\ldots=\beta_{\mathrm{p}}=0 \\
\mathrm{H}_{1}: \text { at least one } \beta_{\mathrm{j}} \neq 0, \mathrm{j}=1,2, \ldots, \mathrm{p}
\end{gathered}
$$

However, because the independent variable used in this study was only one ("class" dummy variable), so, the whole test hypotheses were no different from the partial test, namely:

$\mathrm{H}_{0}: \beta_{1}=0$ (class does not significantly influence students' mathematical concept understanding ability)

$\mathrm{H}_{1}: \beta_{1} \neq 0$ (class has a significant effect on students' mathematical concept understanding ability).

The formula for the Gtest statistics ${ }^{2}$ or likelihood ratio test, namely: 
Description:

$$
\mathrm{G}^{2}=-2 \ln \left[\frac{\left(\frac{\mathrm{n}_{1}}{\mathrm{n}}\right)^{\mathrm{n}_{1}}-\left(\frac{\mathrm{n}_{0}}{\mathrm{n}}\right)^{\mathrm{n}_{0}}}{\sum_{\mathrm{i}=1}^{\mathrm{n}} \widehat{\pi}_{\mathrm{i}}^{\mathrm{yi}}\left(1-\widehat{\pi}_{\mathrm{i}}\right)^{(1-\mathrm{yi})}}\right]
$$

$\mathrm{n}_{1}=$ number of observations which have a value of $\mathrm{y}=1$

$\mathrm{n}_{0}=$ number of observations that have a value of $\mathrm{y}=0$

$\mathrm{n}=\mathrm{n}_{1}+\mathrm{n}_{0}$

Test statistics $\mathrm{G}^{2}$ follows the distribution of chi-square, then testing was done by comparing the statistical values of the $\mathrm{G}^{2}$ test to the chi-square table with free degrees of $\mathrm{v}$ (number of parameters) at the real level of $\alpha$. If the value of $\mathrm{G}^{2}>\chi^{2}(\mathrm{v}, \alpha)$ or $\mathrm{p}$-value $<\alpha$, then $\mathrm{H}_{0}$ is rejected.

Testing the goodness of the Probit regression model was done to measure the accuracy of the regression model in estimating the true value. The method used was the Pearson Goodness of Fit. The hypothesis is:

$\mathrm{H}_{0}$ : The model is not fit

$\mathrm{H}_{1}$ : The model is fit

Statistical test for testing the goodness of Probit regression model is defined as:

$$
\chi^{2}=\sum_{\mathrm{i}=1}^{\mathrm{m}} \quad \frac{\left(\mathrm{o}_{\mathrm{i}}-(\mathrm{e}) \mathrm{i}\right)^{2}}{\mathrm{e}} \mathrm{i}
$$

Description:

m: number of observations

$\mathrm{O}_{\mathrm{i}}$ : the frequency of the observed or real occurred in the category of to- $\mathrm{i}$

$\mathrm{e}_{\mathrm{i}}$ the expected frequency in the category of to-i

$\mathrm{i}=1,2,3, \ldots, \mathrm{m}$.

Criteria for rejection of $\mathrm{H}_{0}: \mathrm{H}_{0}$ is rejected if $\chi^{2}$ test $>\chi^{2}$ tables or $\mathrm{p}$-value $<\alpha$ (Agresti, 2002).

\section{THE RESULTS OF THE RESEARCH AND THE DISCUSSION}

The results of research done on April - May 2019 are shown in Figure 1. Figure 1 shows that the class that applied the Problem-based learning model assisted by Cabri 3D obtained the average score of 70 while the class that applied the Problem-based Learning model without Cabri 3D obtained the average score of 59. Thus, it can be said that the class that applied the PBL learning model assisted by Cabri 3D obtained a greater average score.

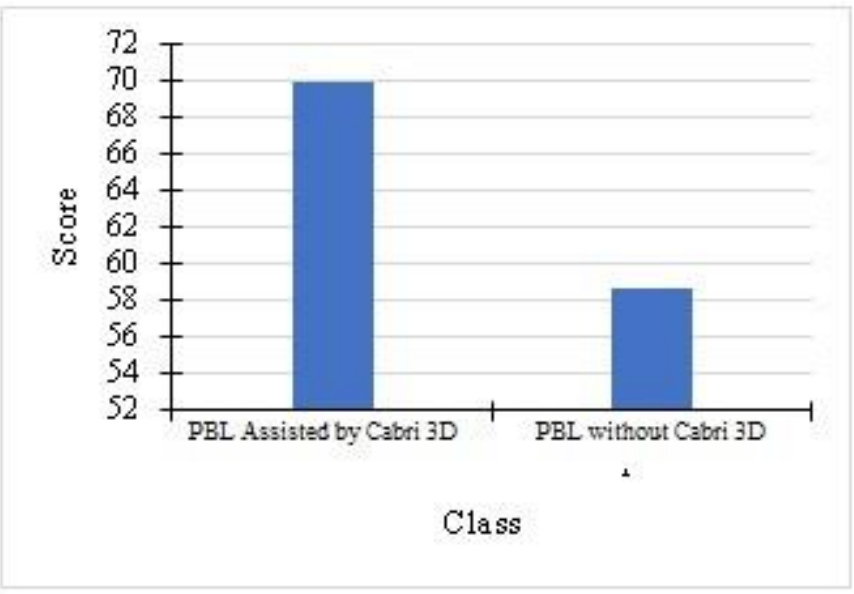

Figure 1. Average Score of Students' Mathematical Understanding Ability per Class 
The results of the Probit regression parameter estimation can be seen in Table 1. Based on Table 1, the Probit regression model obtained is as follows: Probit (students' mathematical concept understanding ability) $=0.221+0.302$ class. Then, From Table 1 , you can also see the partial test results for the "Class" free variable in the significance value column, which is 0,000 . This value is very small, less than the level of significance (significance level) set by researchers that is equal to $5 \%$. This shows that at the real level of $5 \%$, the variable dummy "class" significantly affects the likelihood or opportunity of students' mathematical concept ability.

Table 1. Estimated Values of Probit Regression Analysis

\begin{tabular}{ccccc}
\hline Parameters & Estimated for Default & Errors & Z & Sig. \\
\hline Class & 0.302 & 0.032 & 9,568 & 0,000 \\
Intercept & 0,221 & 0,022 & 10,213 & 0,000 \\
\hline
\end{tabular}

Based on Table 1, the students who were in the class that applied the Cabri 3D obtained a $70 \%$ chance of success in students' mathematical concept understanding ability. Students who got the PBL model without Cabri 3D obtained a 51\% chance of success.

Table 2. Pearson Goodness-of-Fit

\begin{tabular}{c|c|c}
\hline Chi-Square & Df & Sig. \\
\hline 929384 & 65 & $.00^{\mathrm{A}}$ \\
\hline
\end{tabular}

The significance value obtained was $0.000<0.05$, so that on testing the suitability of the model, $\mathrm{H}_{0}$ is rejected. This means that at the $5 \%$ level, it can be concluded that the Probit regression model in the independent variable class is suitable for estimating the Probit values of students' mathematical concept understanding abilities.

Based on previous research, student worksheet assisted by Cabri 3D can improve students' concept understanding so that the learning process becomes effective and very influential (Hendriana et al., 2019), The previous research does not explain how much influence, but in this study, Cabri 3D-assisted learning is very influential in improving students' mathematical concept understanding, which is $70 \%$, greater than the class that did not apply the Cabri 3D. Also, Cabri 3D can increase the effectiveness of students' problem-solving abilities (Pujiastuti, 2013), and influences students' mathematical spatial abilities in using Brain-Based Learning assisted by Cabri 3D (Hendriana et al., 2019).

\section{CONCLUSION AND SUGGESTION}

Based on the results of research, it can be concluded that the use of instructional media technology that is 3D Cabri software integrated with the Problem-based Learning model can significantly affect the students' concept understanding ability. The students who were taught by using the Problem-based Learning model without the help of Cabri 3D obtained a 19\% lower chance of success in mathematical concept understanding. Viewed from the average scores obtained, the class that applied the Problem-based Learning model assisted by Cabri 3D obtained an average score of 70 while the class that applied the Problem-based Learning without Cabri 3D obtained an average score of 59. 
From these findings, it is suggested to the teachers to be able to utilize the Cabri 3D software to assist the learning process in the classroom. Therefore, this software is statistically significant in increasing the students' mathematical concepts understanding ability on planes material. The use of Cabri 3D can help students and teachers to overcome some difficulties in the learning and teaching process, as well as make learning geometry easier and more interesting.

\section{REFERENCES}

Accascina, G., \& Rogora, E. (2006). Using Cabri3D Diagrams for Teaching Geometry. The International Journal for Technology in Mathematics Education, 13(1).

Agresti, A. (2002). Categorial Data Analysis (2nd ed.). Canada: Wiley-Interscience.

Agresti, A. (2006). An Introduction to Categorical Data Analysis: Second Edition. In An Introduction to Categorical Data Analysis: Second Edition (2nd ed.). Canada: WileyInterscience.

Aryanti, R., \& Ferdianto, F. (2019). Identifikasi kemampuan visualisasi siswa smp. Ejournal, 1(1), 400-410.

Hartatiana, H., Darhim, D., \& Nurlaelah, E. (2017a). Improving Junior High School Students' Spatial Reasoning Ability Through Model Eliciting Activities with Cabri 3D. International Education Studies, 11(1), 148. https://doi.org/10.5539/ies.v11n1p148

Hartatiana, Darhim, \& Nurlaelah, E. (2017b). Student's Spatial Reasoning through Model Eliciting Activities with Cabri 3D. Journal of Physics: Conference Series, 895(1).

Helaluddin, \& Wijaya, H. (2019). Pengembangan Kompetensi Pendidik Di Perguruan Tinggi Dalam Menyonsong Era Revolusi Industri 4.0. Prosiding Seminar Nasional Pangan, Teknologi Dan Entrepreneurship, 1-7.

Hendriana, B. (2019). Lembar Kerja Peserta Didik Berbasis Cabri 3d Untuk Meningkatkan Pemahaman Konsep Matematis Siswa.Journal of Chemical Information and Modeling, 53(9), 1689-1699.

Hendriana, B., Nuriadin, I., \& Rachmaeni, L. (2019). Pengaruh Model Brain-Based Learning Berbantuan Cabri 3d Terhadap Kemampuan Spasial Matematis Siswa ( The Influence Of Brain-Based Learning Model With Cabri 3d On Student' S Ability Of Spatial Mathematics ).Jurnal THEOREMS, 4(1), 18-28.

Hosmer, D. W., Lemeshow, S., \& Sturdivant, R. X. (2013). Applied Logistic Regression: Third Edition. In Applied Logistic Regression: Third Edition.

Imanullah, D. F., \& Sobari, A. (2019). Pemanfaatan Teknologi Informasi dan Komunikasi dalam Pembelajaran Ski Kelas VIII SMP Islam Plus Daarul Jannah. e-Jurnal Mitra Pendidikan, 3(6), 796-806.

Kristyanawati, M. D., Suwandi, S., \& Rohmadi, M. (2019). Peningkatan Keterampilan Menulis Teks Eksposisi Menggunakan Model Problem Based Learning. Scholaria: Jurnal Pendidikan Dan Kebudayaan, 9(2), 192-202. 
Kusmawati, H., \& Surachman, A. I. (2019). Glokalisasi kurikulum pendidikan agama islam madrasah aliyah keagamaan di era revolusi industri $4.0{ }^{1}$. Pendidikan Dasar, 6(2).

Lebamovski, P., \& Gospodinov, M. (2019). 3D Innovation Technologies in Education. CBU International Conference Proceedings, 7, 484-489.

Lestari, S. I., \& Lies, A. (2019). Pengaruh Penerapan Strategi Pembelajaran Scaffolding terhadap Kemampuan Pemahaman Konsep Matematis Siswa Madrasah Tsanawiyah AlHidayah Singingi Hilir ditinjau dari Motivasi Belajar Siswa. Suska Journal of Mathematics Education, 5(1), 68-76.

Muhammad, M., Purwanto, J., \& Muji Prisnaini, R. (2017). Improving Students' Spatial Skill with Learning Cycle Using Cabri 3D Application in Junior High School. Atlantis Press, 109(Aecon), 333-337.

Pujiastuti, E. (2013). Keefektifan Pembelajaran Model Quantum Teaching Berbantuan Cabri 3D Terhadap Kemampuan Pemecahan Masalah. Kreano: Jurnal Matematika KreatifInovatif, 4(1), 98-104.

Rasmin, Sudia, M., \& Kadir. (2019). Pengaruh Pembelajaran Problem Posing terhadap Kemampuan Pemecahan Masalah Matematis Siswa. Jurnal Pembelajaran Berpikir Matematika, 3(2), 85-95.

Sopia, N., Hartoyo, A., \& Sugiatno. (2019). Pengembangan Pemahaman Konseptual Dan Disposisi Matematis Siswa Melalui Penerapan Pendekatan Problem Solving Di Sma. $J$ PiMat, 1(1), 11-20.

Sumliyah. (2019). Penerapan Media Pembelajaran Cabri 3d Pada Kemampuan Pemahaman Konsep Matematika Smk. Jurnal Int Sgral, 10(1), 16-27.

Tanjung, H. S., \& Nababan, S. A. (2019). Pengembangan Perangkat Pembelajaran berbasis Masalah untuk Meningkatkan Kemampuan Pemecahan Masalah dan Komunikasi Matematis Siswa SMA Negeri 3 Kuala Kabupaten Nagan Raya. Genta Mulia: Jurnal Ilmiah Pendidikan, 10(2).

Unaenah, E., \& Sumantri, muhammad S. (2019). Analisis Pemahaman Konsep Matematis Siswa Kelas 5 Sekolah Dasar Pada Materi Pecahan Een. Jurnal Basicedu, 3(1), 106-111.

Waluyo, S. B., \& Siswanto, B. (2019). Upaya Meningkatkan Kemampuan Pemahaman Konsep Matematis dan Rasa Ingin Tahu Siswa Kelas X MIPA 9 SMA N 4 Semarang Melalui Model Problem Based Learning Berbantuan Kartu Soal. 2, 893-898.

Wendayani, Ratnaningsih, N., \& Muhtadi, D. (2019). Implementasi Model Pembelajaran OSBORN untuk Menggali Kemampuan Berpikir Lateral Matematik Ditinjau dari Gaya Belajar Peserta Didik. Journal of Authentic Research on Mathematics Education (JARME), 1(2), 19-30.

Witanto, Y. (2019). Learning The Concept Of Cube Using Cabri 3D V2. Atlantis Press, 303, $161-163$.

Yanty Putri Nasution, E. (2017). Meningkatkan Kemampuan Spasial Siswa Melalui 


\section{$\mathbf{a} \int \delta \mu$ \\ allabar : Jurnal Pondidilkan Matomatika
P-ISSN $2086-5872$
e-ISSN $2540-7562$}

Al-Jabar: Jurnal Pendidikan Matematika

Vol. 10, No. 2, 2019, Hal 319 - 326

Pembelajaran Geometri Berbantuan Cabri 3D. M A T H L I N E : Jurnal Matematika Dan Pendidikan Matematika, 2(2), 179-194. https://doi.org/10.31943/mathline.v2i2.45

Zulfa, A., Warniasih, K., \& Wardono, W. (2019). Peningkatan Pemahaman Konsep Matematika melalui Model Problem Based Learning pada Siswa Kelas XI IPS 2 SMA Negeri 1 Gamping. PRISMA; Prosiding Seminar Nasional Matematika, 2, 371-375. 